BIODIK: Jurnal IImiah Pendidikan Biologi
ISSN 2580-0922 (online), ISSN 2460-2612(print)
Volume 6, Nomor 02, Tahun 2020, Hal. 118-132
Available online at:
https://online-journal.unja.ac.id/biodik

Research Article OPEN ACCESS

\title{
Pengembangan Bahan Ajar Berbasis Komik Materi Pteridophyta pada Mahasiswa Pendidikan Biologi UIN Alauddin Makassar
}

\section{(The Development of Comic-based Teaching Materials on Pteridophyta for Biology Education Students at UIN Alauddin Makassar)}

\author{
Syahriani ${ }^{*}$, Sofyan \\ Jurusan Pendidikan Biologi Fakultas Tarbiyah dan Keguruan UIN Alauddin Makassar \\ Kampus II Jalan. H. M. Yasin Limpo Nomor 36 Samata-Gowa \\ Sulawesi Selatan-Indonesia 92118 Telepon: (0411) 424835 \\ *Corresponding Author:syahriani.rahman@uin-alauddin.ac.id
}

\begin{tabular}{|c|c|}
\hline Informasi Artikel & ABSTRACT \\
\hline $\begin{array}{l}\text { Submit: } 08-05-2020 \\
\text { Diterima: } 17-05-2020 \\
\text { Dipublikasikan:04 - 06-2020 }\end{array}$ & 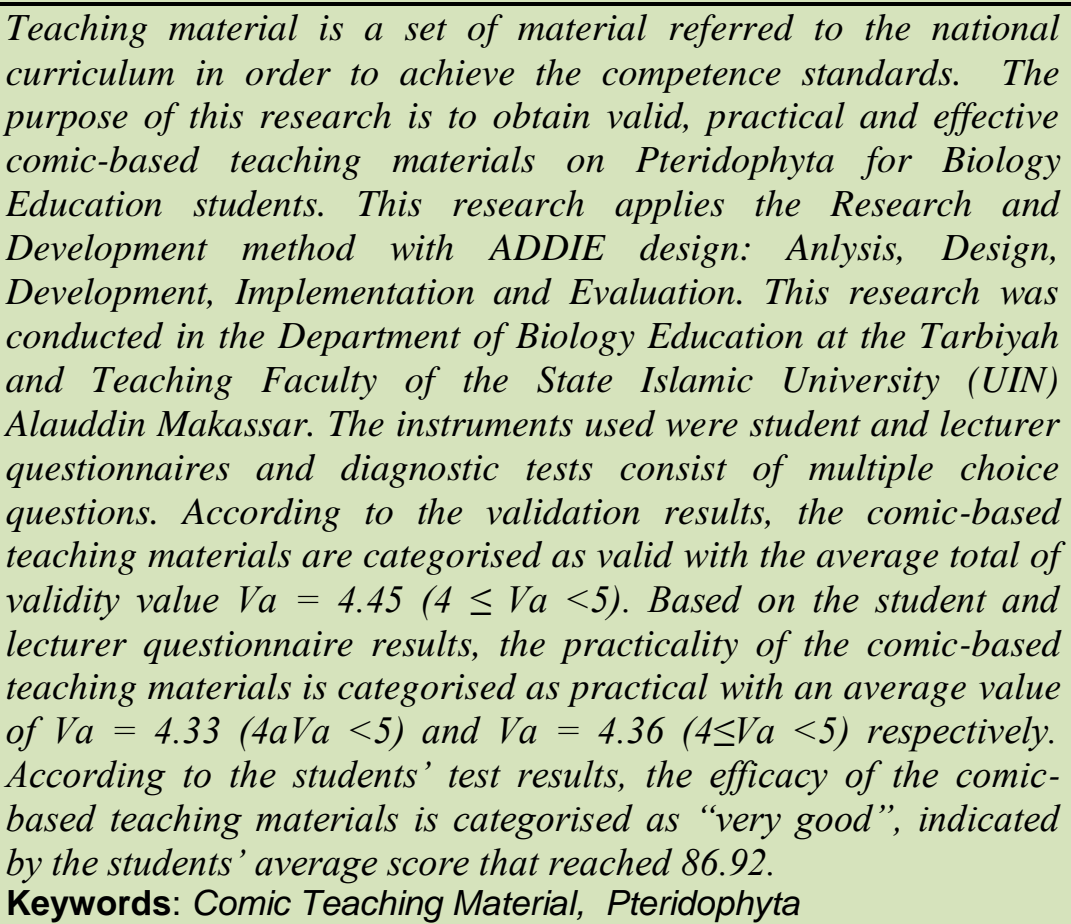 \\
\hline Penerbit & ABSTRAK \\
\hline $\begin{array}{l}\text { Program Studi Pendidikan } \\
\text { Biologi, Fakultas Keguruan dan } \\
\text { Ilmu Pendidikan, Universitas } \\
\text { Jambi }\end{array}$ & $\begin{array}{l}\text { Bahan ajar adalah seperangkat materi pelajaran yang mengacu } \\
\text { pada kurikulum yang digunakan dalam rangka mencapai standar } \\
\text { kompetensi dan kompetensi dasar yang telah ditentukan. Tujuan } \\
\text { dari dilakukannya penelitian ini yaitu untuk mendapatkan bahan ajar } \\
\text { berbasis komik pada materi Pteridophyta pada mahasiswa } \\
\text { Pendidikan Biologi yang valid, praktis dan efektif. Penelitian ini } \\
\text { menggunakan metode Research and Development dengan desain } \\
\text { ADDIE: Anlysis, Design, Develpment, Implementation and } \\
\text { Evaluation. Penelitian ini dilaksankan di Jurusan Pendidikan Biologi } \\
\text { Fakultas Tarbiyah dan Keguruan Universitas Islam Negeri (UIN) } \\
\text { Alauddin Makassar.Instumen yang digunakan berupa angket repson } \\
\text { mahasiswa, dosen dan diagnostic test berupa pilihan ganda } \\
\text { Berdasarkan hasil penilaian validator, tingkat kevalidan bahan ajar } \\
\text { berbasis komik materi pteridophyta berada pada kategori valid }\end{array}$ \\
\hline
\end{tabular}



maka tingkat kepraktisan bahan ajar berbasis komik materi pteridophyta berada pada kategori praktis dengan nilai rata-rata $\mathrm{V}_{\mathrm{a}}=$ $4.33(4 \leq \mathrm{Va}<5)$ dan nilai rata-rata total kevalidan angket respon Dosen terhadap komik pembelajaran yaitu $V_{a}=4.36(4 \leq \mathrm{Va}<5)$. Berdasarkan hasil tes belajar mahasiswa tingkat keefektifan bahan ajar berbasis komik materi pteridophyta berada pada kategori sangat baik dengan nilai rata-rata hasil mahasiswa yaitu 86.92

Kata kunci: Bahan Ajar Komik, Pteridophyta.

\section{PENDAHULUAN}

Pendidikan merupakan sarana dalam meningkatkan derajat suatu bangsa. Bangsa dengan pendidikan yang bagus maka akan menghasilkan peradaban yang bermutu. Pendidikan sangat penting terhadap suatu bangsa sehingga mustahil suatu bangsa maju tanpa adanya peningkatan terhadap kualitas pendidikan karena dengan pendidikan akan terbentuk sumber daya manusia yang berkualitas dan memiliki kecakapan dalam menguasai ilmu pengetahuan dan teknologi (Ubhiyati, 2007). Mengingat sangat pentingnya pendidikan bagi kehidupan bangsa dan Negara diperlukan adanya sistem yang dapat mengomunikasikan segala bentuk pengetahuan dalam satu media yang berkualitas dalam pembelajaran (Bingimlas, 2009).

Dua faktor yang mempengaruhi kegiatan pembelajaran mahasiswa yaitu faktor internal mahasiswa yang meliputi aspek fisiologis dan psikologis. Di samping itu, faktor eksternal juga turut berpengaruh yang meliputi lingkungan sosial dan nonsosial (Astuti, 2012). Sikap mahasiswa yang cenderung pasif dalam proses pembelajaran akan menimbulkan rendahnya minat dan motivasi belajar (Arsyad, 2009). Salah satu wujud usaha konkrit yang dilakukan pendidik untuk meningkatkan minat dan motivasi mahasiswa dalam belajar yaitu dengan melakukan inovasi dalam pembelajaran, misalkan saja membuat bahan ajar yang menarik untuk kemudian digunakan mahasiswa dalam pembelajaran.

Bahan ajar adalah seperangkat materi pelajaran yang mengacu pada kurikulum yang digunakan dalam rangka mencapai standar kompetensi dan kompetensi dasar yang telah ditentukan (Fajriah \& Anggereini, 2016; Lestari, 2013). Bahan ajar berguna bagi pendidik dan mahasiswa. Bagi Pendidik, berfungsi membantu dalam pembelajaran, yaitu mengarahkan aktifitas dan membantu dalam mengajarkannya kepada mahasiswa. Sedangkan bagi mahasiswa digunakan sebagai pedoman yang seharusnya dipelajari dalam proses pembelajaran. Bahan ajar berfungsi menyusun dan mengawasi proses pemrolehan informasi mahasiswa. Bahan ajar yang menggunakan gambar akan membantu mahasiswa dalam memahami pelajarannya (Arsyad, 2011). Bahan ajar yang menggunakan gambar dan animasi dapat membantu mahasiswa dalam memahami konsep yang dipelajari (Sadikin et al., 2018). Hal ini disebabkan oleh adanya gambar dan sajian bahasa 
yang menjelaskan maksud dari gambar akan membuat mahasiswa dapat menyaksikan langsung apa yang diajarkan pendidik sehingga pembelajaran menjadi lebih konkrit dan meminimalisir adanya penafsiran ganda .

Komik merupakan salah satu bentuk bahan ajar yang didalamnya terdapat gambar yang disertai dengan penjelasan gambar. Komik sebagai sumber belajar yang dapat membantu mahasiswa dan dapat menggantikan posisi pendidik dalam kegiatan pembelajaran baik di kelas maupun di luar kelas (Saputro, 2015). Komik dapat digunakan dalam proses pembelajaran dua arah, yaitu sebagai alat bantu mengajar dan sebagai media belajar yang dapat digunakan sendiri oleh mahasiswa.

Berdasarkan observasi yang dilakukan pada mahasiswa semester II mata kuliah botani tingkat rendah, melihat banyaknya materi yang disajikan pada mata kuliah tersebut maka pembelajaran masih berjalan dengan membosankan dan menyebabkan mahasiswa cepat jenuh, hal ini ditandai dengan masih adanya mahasiswa yang bercerita pada saat pembelajaran telah berjalan 30 menit. Diharapkan dengan adanya bahan ajar berbasis komik yang dikembangkan dalam penelitian ini, nantinya dapat digunakan mahasiswa dalam memahami materi dan pembelajaran dapat berjalan lebih menarik.

\section{METODE PENELITIAN}

Jenis penelitian yang digunakan dalam penelitian ini yaitu jenis penelitian pengembangan, yang lebih dikenal dengan istilah Research \& Development (R \& D). Penelitian ini merupakan penelitian pengembangan, yaitu suatu jenis penelitian untuk menghasilkan suatu produk. Produk yang dihasilkan adalah bahan ajar berbasis komik pada materi pteridophyta. Model pengembangan yang digunakan adalah ADDIE yang dikembangkan oleh Dick and Carry (1996) dan terdiri atas lima fase, yaitu: (1) analisis (analyze), (2) perancangan (design), (3) pengembangan (development), (4) implementasi (implementation), (5) evaluasi (evaluation).

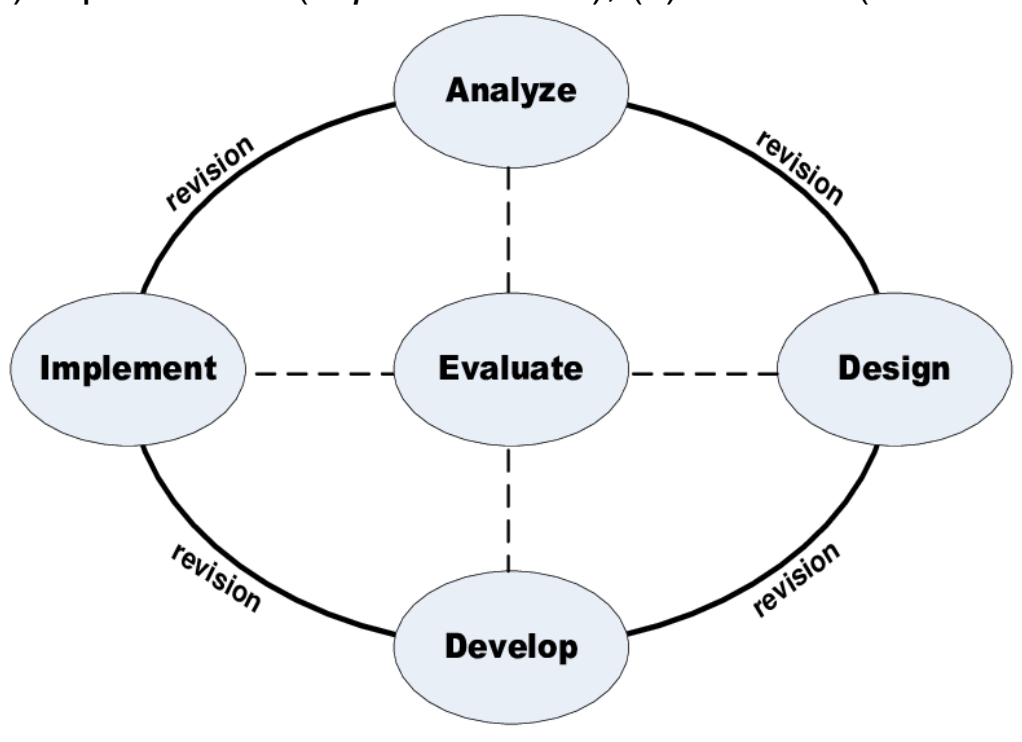

Gambar.1 Alur tahapan ADDIE

Subjek penelitian adalah Mahasiswa Jurusan Pendidikan Biologi Semester II Fakultas Tarbiyah dan Keguruan UIN Alauddin Makassar sebanyak 24 orang 
Mahasiswa. Data dikumpulkan dengan cara: (1) Uji kevalidan menggunakan lembar validasi media pembelajaran, informasi yang diperoleh melalui instrumen ini digunakan sebagai masukan dalam merevisi media pembelajaran yang telah dikembangkan hingga menghasilkan produk akhir yang valid. (2) Uji kepraktisan diperoleh dari instrumen penelitian berupa angket respon dosen. (3) Uji keefektifan diperoleh dari instrumen penelitian berupa butir-butir tes pilihan ganda (Maksum, 2012). Keseluruhan instrumen sebelum digunakan divalidasi oleh tim ahli materi sebanyak dua orang.Teknik analisis data penelitian dikelompokkan menjadi 3 yaitu, kevalidan, keefektifan dan kepraktisan. Kriteria analisis data tersebut, disajikan seperti tabel 1,2 dan 3 .

Tabel 1. Kategori Tingkat Kevalidan

\begin{tabular}{cc}
\hline Nilai & Keterangan \\
\hline $3,5 \leq \mathrm{V} \leq 4,0$ & Sangat valid \\
$2,5 \leq \mathrm{V}<3,5$ & Valid \\
$1,5 \leq \mathrm{V}<2,5$ & Cukup valid \\
$0 \leq \mathrm{V}<1,5$ & Tidak valid \\
$\mathrm{Va}=5$ & Sangat Tinggi \\
\hline Keterangan: $\mathrm{V}=$ nilai rata-rata kevalidan dari semua validator
\end{tabular}

Produk di uji kepraktisannya untuk melihat respon pengguna. Uji kepraktisan diperoleh dari instrumen penelitian berupa angket respon dosen. Kategori tingkat kepraktisan dapat dilihat pada tabel 2.

Tabel 2 Kategori Tingkat Kepraktisan

\begin{tabular}{cc}
\hline Nilai & Keterangan \\
\hline $1 \leq \mathrm{Va}<2$ & Sangat rendah \\
$2 \leq \mathrm{Va}<3$ & Rendah \\
$3 \leq \mathrm{Va}<4$ & Sedang \\
$4 \leq \mathrm{Va}<5$ & Tinggi \\
$\mathrm{Va}=5$ & Sangat Tinggi \\
\hline
\end{tabular}

Keterangan $: \mathrm{Va}=$ nilai rata-rata kepraktisan

Keefektifan bahan ajar yang dikembangkan dianalisis melalui data pengukuran hasil belajar mahasiswa. Pencapaian hasil belajar diarahkan pada pencapaian secara individu. Keefektifan bahan ajar dilihat dari hasil positif yang diberikan oleh sumber belajar kepada subjek penelitian yaitu berdasarkan peningkatan hasil belajar mahasiswa. Sumber belajar dikatakan efektif jika memenuhi indikator rata-rata skor tes hasil belajar mahasiswa adalah tuntas (Maksum, 2012).Menurut (Arikunto, 2013), hasil belajar tersebut dikelompokkan dengan mengacu pada pengkategorian yang ditunjukkan pada Tabel 3.

Tabel 3. Pedoman Pengkategorian Hasil Belajar

\begin{tabular}{ll}
\hline \multicolumn{1}{c}{ Interval Nilai (angka 100) } & Pengkategorian \\
\hline $80-100$ & Sangat baik \\
$66-79$ & Baik \\
$56-65$ & Cukup \\
$40-55$ & Kurang \\
$0-39$ & Sangat kurang \\
\hline
\end{tabular}




\section{HASIL DAN PEMBAHASAN}

Bahan ajar komik sebagai sumber belajar mahasiswa pada materi Pteridophyta telah diteliti dan dikembangkan dengan mengacu pada model pengembangan $A D D I E$, yang terdiri dari 5 tahap yaitu Analisis (Analysis), Desain (Design), Pengembangan (Development), Implementasi (Implementation), dan Evaluasi (Evaluation). Kelima tahap dalam model pengembangan ADDIE dilaksanakan dalam penelitian dan pengembangan untuk menghasilkan bahan ajar berupa komik sebagai sumber belajar pada materi Pteridophyta untuk mahasiswa yang valid, praktis, dan efektif.

\section{Analisis (Analysis)}

Tahap analisis yang dilakukan meliputi 3 kegiatan yaitu: analisis kebutuhan mahasiswa dan dosen, analisis karakteristik mahasiswa, dan analisis materi pada silabus.

a. Analisis kebutuhan mahasiswa dan Dosen

Hasil observasi berupa wawancara yang dilakukan pada mahasiswa semester II mata kuliah botani tingkat rendah, melihat banyaknya materi yang disajikan pada mata kuliah tersebut maka pembelajaran masih berjalan dengan membosankan dan menyebabkan mahasiswa cepat jenuh. Selain itu, dari segi sumber belajar yang digunakan oleh mahasiswa yang berupa buku paket dan mengandalkan koneksi internet. Namun, beberapa mahasiswa tidak memiliki sumber belajar tersebut dengan berbagai alasan, diantaranya tidak memiliki biaya yang cukup untuk membeli semua buku paket pada setiap mata kuliah khususnya pada mata kuliah botani tingkat rendah. Alasan lainnya adalah hasil fotocopy yang tidak berwarna, dan berbagai alasan lainnya. Selain wawancara dengan mahasiswa, dilakukan juga wawancara dengan Dosen mata kuliah.

Hasil wawancara yang dilakukan kepada Dosen mata kuliah botani tingkat rendah diperoleh informasi yaitu salah satu materi pada botani tingkat rendah yang membutuhkan penjelasan tidak cukup dengan gambar, dan buku teks adalah materi Pteridophyta. Materi Pteridophyta membutuhkan sebuah sumber pembelajaran yang mampu menjelaskan bagaimana habitat, cara hidup, reproduksi dan klasifikasi. Salah satu bahan pembelajaran yang bisa digunakan untuk materi Pteridophyta adalah melalui bahan ajar komik.

b. Analisis karakteristik mahasiswa

Hasil analisis karakteristik mahasiswa melalui observasi di kelas dan wawancara dengan mahasiswa diperoleh informasi bahwa sebagian besar mahasiswa memiliki ketertarikan yang tinggi pada media-media visual berupa gambar yang dapat menarik perhatian dan minat mahasiswa untuk belajar khusus materi Pteridophyta, karena cakupan materi Pteridophyta cukup luas dimana mahasiswa harus mengidentifikasi dan mengamati habitat, cara hidup, reproduksi setiap spesies dari beberapa family Pteridophyta.

c. Analisis Materi pada Silabus

Proses belajar mengajar dilaksankan dengan mengacu pada silabus mata kuliah Jurusan Pendidikan Biologi yang terdiri dari banyak materi pokok dan selanjutnya dituangkan dalam bentuk RPS. Peneliti memilih materi Pteridophyta 
dengan pertimbangan berdasarkan analisis alokasi waktu untuk semester genap, dengan jumlah jam perminggu adalah 3 SKS (150 menit). Pada semester genap, berdasarkan pembagian waktu, materi untuk Pteridophyta memperoleh waktu pembelajaran selama 2 kali pertemuan dari total 16 kali pertemuan. Namun pada kenyataannya, alokasi waktu tersebut tidak cukup digunakan untuk menyampaikan materi Pteridophyta karena banyaknya konsep yang harus dijelaskan mulai dari habitat, cara hidup, reproduksi dan klasifikasi setiap famili dari Pteridophyta ditambah dengan kegiatan praktikum. Di sisi lain, alokasi waktu tersebut bisa berkurang dikarenakan adanya kegiatan lain di luar kegiatan yang telah direncanakan pada saat perhitungan jumlah jam efektif atau Dosen berhalangan mengajar sehingga menyebabkan penyelesaian materi menjadi tidak tepat pada waktunya. Oleh karena itu, Peneliti memilih materi Pteridophyta untuk dikembangkan menjadi sebuah bahan ajar berupa komik agar mahasiswa dengan mudah mampu menjelaskan setiap spesies dari family Pteridophyta mulai dari habitat, cara hidup, reproduksi dan klasifikasi dengan adanya bantuan komik dengan menyajikannya dalam sebuah bahan pembelajaran berupa komik.

\section{Desain (Design)}

Bahan ajar komik pada materi Pteridophyta didesain dengan mempertimbangkan kebutuhan mahasiswa dan Dosen serta karakter mahasiswa, dimana pada Bahan ajar komik ini ditampilkan berbagai gambar-gambar sebagai bentuk visualisasi materi dan pada Bahan ajar komik tentang ciri tumbuhan paku, habitat, reproduksi, klasifikasi dan peranannya dalam kehidupan. Komik pembelajaran ini juga terdapat narasi penjelasan materi sebagai bentuk visual materi pembelajaran Pteridophyta. Selain itu, Bahan ajar komik didesain sesuai dengan Kompetensi Dasar, indikator pembelajaran, dan tujuan pembelajaran yang harus dicapai oleh mahasiswa pada materi Pteridophyta. Dengan demikian diharapkan Bahan ajar komik dapat menambah motivasi dan minat mahasiswa dalam belajar serta memudahkan mahasiswa dalam belajar. Secara keseluruhan desain dari komik pembelajaran terdiri atas Cover, gambar, cerita terkait spesies tumbuhan paku setiap famili, dan teks materi pembelajaran. 


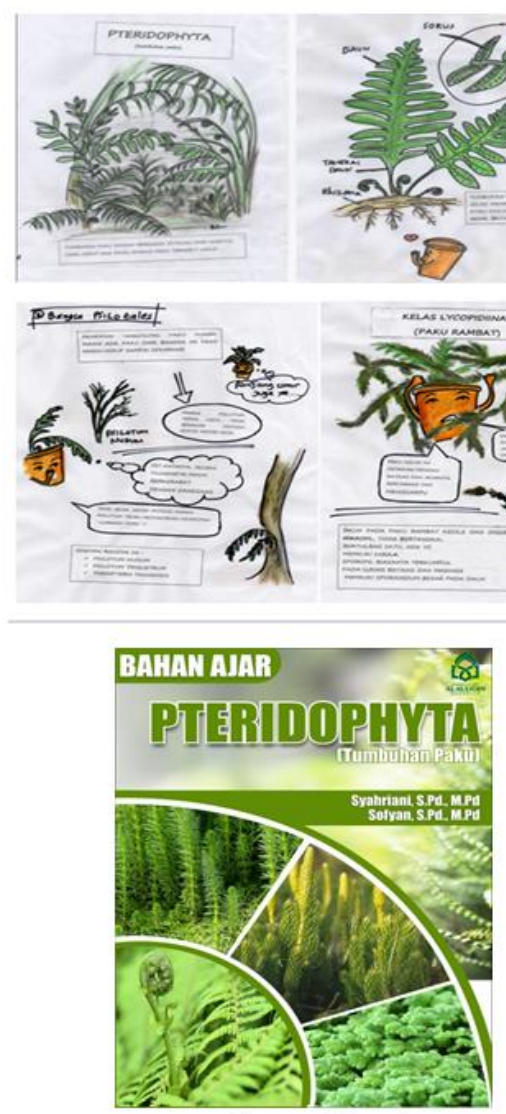

Cover Komik
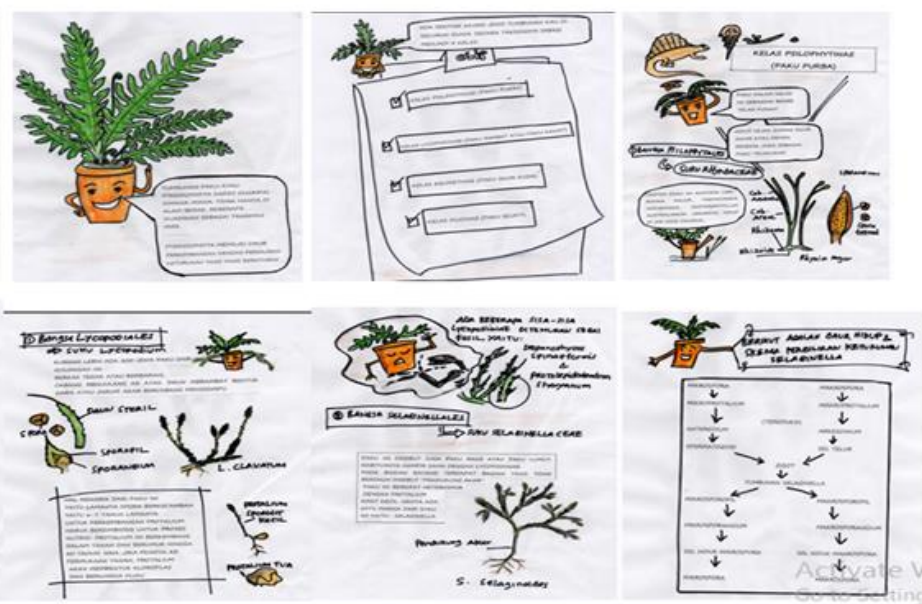

Konten Komik

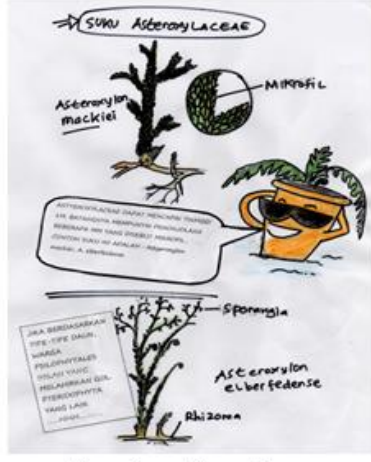

Konten Komik

Gambar. 2 Tampilan Komik

\section{Pengembangan (Development)}

Tahap pengembangan merupakan tahap untuk menghasilkan produk akhir dari proses desain. Tahap pengembangan meliputi pengembangan Bahan ajar komik sebagai sumber belajar pada materi Pteridophyta dan validasi Bahan ajar komik oleh dua validator ahli.

\section{a. Pengembangan Bahan Ajar Komik}

Pembuatan komik dimulai dengan penyusunan alur cerita dimana alur yang digunakan adalah alur campuran, setelah itu pembuatan naskah yang terdiri dari prolog dan percakapan antar karakter yang di dalamnya membicarakan tentang kelas, ordo dan famili dari Pteridophyta. Selanjutnya pembuatan karakter pada komik disesuaikan dengan peran setiap karakter, yang dibuat dengan menggunakan sketsa atau gambar manual. Karakter komik diantaranya adalah paku purba (Psilophytinae), paku rambat (Licopydinae), Paku ekor kuda (Equisetinae) dan Pakis (Filicinae). 


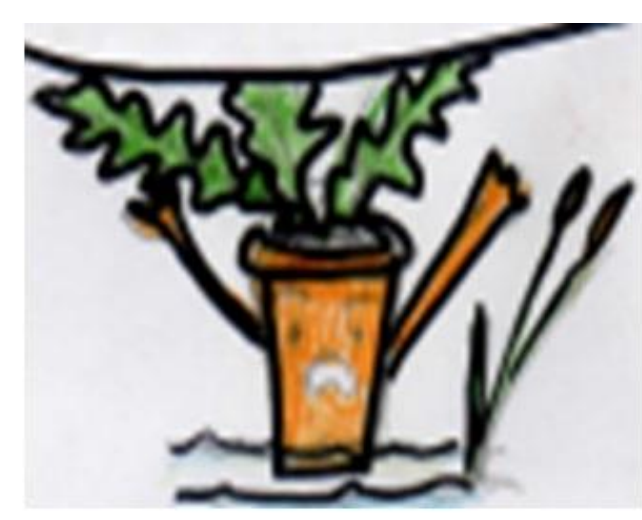

Paku Purba

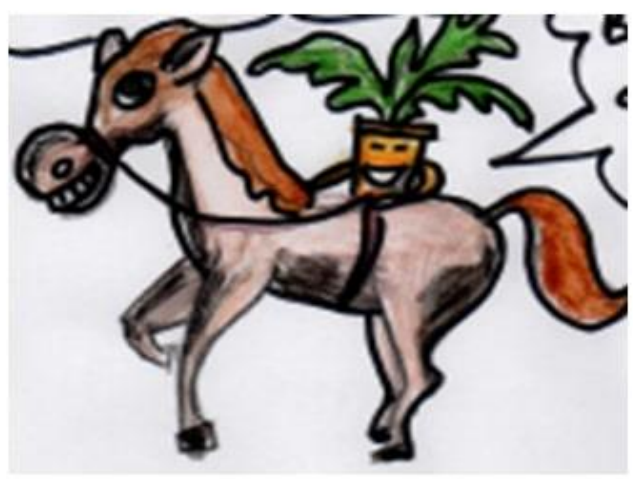

Paku Ekor Kuda

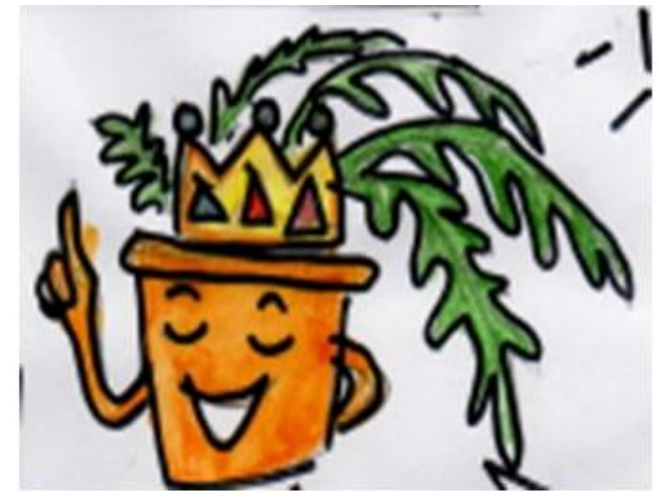

Paku Rambat

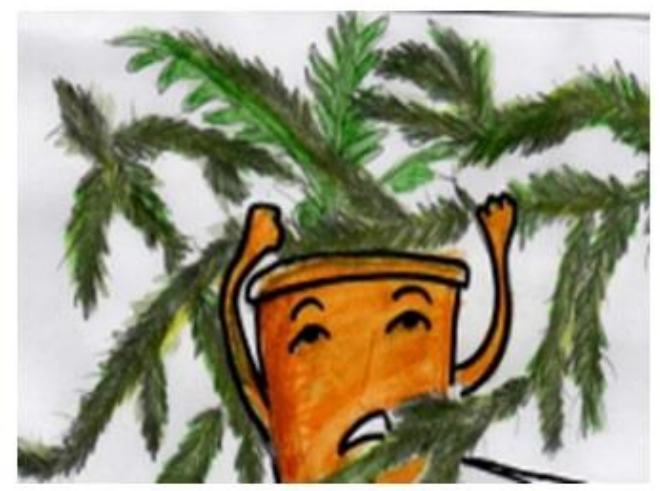

Pakis

\section{Gambar 3. Karakter Karakter Komik}

Menariknya, ada beberapa karakter yang merupakan kelas dari Pteridophyta yang langsung memerankan fungsinya pada komik tersebut yakni spesies dari kelas paku purba (Psilophytinae), paku rambat (Licopydinae), Paku ekor kuda (Equisetinae) dan Pakis (Filicinae). paku sehingga mahasiswa akan lebih mudah memahami materi pada komik, khususnya pada materi Pteridophyta. Bahan ajar komik disajikan dalam bentuk hand out sehingga dalam penggunaanya tidak memerlukan laptop/komputer dan smartphone. Tampilan Bahan ajar komik dilengkapi dengan menggunakan cover yang menarik, dengan gambar tokoh yang menunjukkan spesies dari tumbuhan Pteridophyta, dan disertai isi materi yang kompleks yang dibuat dalam bentuk cerita.

b. Validasi Bahan ajar komik oleh dua validator ahli.

Kegiatan validasi dilakukan dengan memperlihatkan Bahan ajar komik yang telah dibuat disertai dengan lembar angket observasi keterlaksanaan, lembar angket respon mahasiswa (mahasiswa) dan Dosen, Rencana Pelaksanaan Pembelajaran (RPP), dan soal pilihan ganda. Penilaian terhadap Bahan ajar komik dilakukan dengan mengisi lembar validasi yang telah dibuat. 
Uji validasi dilakukan oleh dua validator ahli yang merupakan dosen Jurusan Pendidikan Biologi yaitu Jamilah, S.Si., M.Si. dan Ahmad Ali, S.Pd., M.Pd. Peneliti memperoleh hasil penilaian produk dari validator, jadi validator tidak hanya memberikan saran kepada peneliti, tetapi juga memberikan penilaian terhadap produk yang dihasilkan. Peneliti selanjutnya akan merevisi hasil kerja sesuai dengan umpan balik yang diterima dari validator.

Validator memberikan penilaian terhadap instrumen dan Bahan ajar komik yang telah dikembangkan. Penilaian yang diperoleh dari validator kemudian dianalisis untuk mengetahui nilai kevalidan instrumen dan Bahan ajar komik tersebut. Adapun hasil penilaian tersebut dipaparkan sebagai berikut.

Tabel 4. Hasil Validasi komik Pembelajaran Biologi

\begin{tabular}{llcc}
\hline No & Aspek yang dinilai & Skor rata-rata & Keterangan \\
\hline 1 & Kelayakan isi & 4.17 & Valid \\
2 & Kelayakan penyajian & 4.36 & Valid \\
3 & Kelayakan media & 4.57 & Valid \\
4 & Kelayakan bahasa & 4.7 & Valid \\
Rata-rata Va & 4.45 & Valid \\
\hline
\end{tabular}

Berdasarkan hasil analisis yang ditunjukkan pada tabel 4 di atas dapat dijelaskan bahwa nilai rata-rata total kevalidan komik pembelajaran yaitu $\mathrm{V}_{\mathrm{a}}=4.45$, nilai tersebut masuk ke dalam kategori "valid" $(4 \leq \mathrm{Va}<5)$. Jadi, setelah ditinjau dari keseluruhan kriteria, dapat disimpulkan bahwa komik pembelajaran dinyatakan layak untuk digunakan.

Menurut (Arikunto, 2013), validitas adalah tingkat kevalidan suatu instrumen. Instrumen yang valid adalah instrumen yang mampu mengukur apa yang seharusnya diukur. Suatu instrumen yang valid atau sahih mempunyai validitas tinggi. Sebaliknya, instrumen yang kurang valid berarti memiliki validitas rendah. Uji kevalidan ini masuk ke dalam tahap development (pengembangan).

Hasil validasi prototype 1 yang telah dilakukan ternyata diperoleh bahwa prototype 1 yang dihasilkan sudah tergolong valid tetapi masih perlu ada perbaikan. Hal ini disebabkan karena gambar dari komik yang digunakan tidak terlalu jelas. Selain itu masih terdapat beberapa bagian antara gambar komik dan penjelasan materi yang kurang sesuai. Prototype 2 merupakan hasil revisi dari prototype 1 , berdasarkan hasil validasi yang telah dilakukan ternyata diperoleh bahwa prototype 2 sudah tergolong valid. Hasil validasi di atas, menunjukkan bahwa secara komik pembelajaran yang dikembangkan sudah terkategori valid dan siap diujicobakan.

Kriteria penilaian yang digunakan untuk menentukan kevalidan komik pembelajaran terdiri dari 4 aspek yaitu kelayakan isi, kelayakan penyajian, kelayakan media dan kelayakan bahasa. Berdasarkan hasil analisis data kevalidan komik pembelajaran diperoleh nilai kevalidan dari validator untuk setiap aspek penilaian yaitu kelayakan isi adalah 4.17; kelayakan penyajian adalah 4.36; kelayakan media adalah 4.57 dan kelayakan bahasa adalah 4.70. Jadi nilai rata-rata kevalidan komik pembelajaran adalah 4.45; dapat disimpulkan bahwa komik pembelajaran termasuk dalam kategori "valid" $(4 \leq \mathrm{Va}<5)$. Hal ini menunjukkan bahwa Bahan ajar 
komiktermasuk dalam kategori "valid" sehingga dapat digunakan sebagai sumber belajar mahasiswa untuk mahasiswa pada materi Pteridophyta

Materi yang ada di dalam Bahan ajar komik sesuai dengan kompetensi dasar pada silabus. Pada pengembangan Bahan ajar komik terdapat perpaduan teks, gambar, cerita, dan penjelasan materi. Semua komponen yang terdapat dalam komik pembelajaran, membuat mahasiswa dapat membaca, melihat gambar, komik, alur cerita dan sehingga dalam belajar mahasiswa mudah memahami isi materi.

Penelitian ini didukung oleh penelitian yang dilakukan (Syafa'ah, 2014) yang berjudul Pengembangan bahan ajar berbasis cerita bergambar/komik materi pokok konsep pembagian dengan pendekatan inquiry siswa kelas III SDN Jatimulyo II Malang. Diperoleh Bahan ajar berbasis cerita bergambar/komik ini dapat dikatakan layak setelah melalui proses validasi dari para ahli dengan hasil validasi ahli materi sebesar $80 \%$ dan $64 \%$, ahli media sebesar $86 \%$, ahli bahasa sebesar $74 \%$, dan praktisi pendidikan sebesar $79 \%$.

Beberapa penelitian juga mengungkapkan bahwa mahasiswa mengingat informasi lebih baik ketika pelajaran dipadukan secara visual karena membantu mahasiswa dari segala usia untuk lebih baik mengelola tujuan pembelajaran dan mencapai keberhasilan akademis (Listiyani \& Widayati, 2012). (Puspitorini et al., 2014), "melalui media komik, seseorang mampu memahami pesan pembelajaran secara lebih bermakna sehingga informasi yang disampaikan melalui media tersebut dipahami secara utuh, sehingga dengan sendirinya informasi akan tersimpan dalam memori jangka panjang".

\section{Implementasi}

Implementasi atau uji coba terbatas dilakukan untuk melihat tanggapan mahasiswa terhadap Bahan ajar komik pada materi Pteridophyta yang digunakan pada saat pembelajaran. Pada saat uji coba, peneliti juga melakukan uji kepraktisan dengan angket observasi keterlaksanaan Bahan ajar komik dalam kelas. Angket observasi keterlaksanaan diisi oleh dua observer. Setelah uji coba selesai dilaksanakan, begitu juga dengan pengisian angket observasi keterlaksanaan yang telah diisi oleh dua orang observer, peneliti selanjutnya melanjutkan uji keterlaksanaan untuk melihat respon mahasiswa dan Dosen terhadap komik pembelajaran biologi. Setelah dilakukan uji coba terbatas dan kepraktisan, peneliti melakukan uji keefektifan dengan melihat hasil belajar mahasiswa.

a. Kepraktisan komik Pembelajaran Biologi

Kepraktisan Bahan ajar komik dapat dilihat dari observasi keterlaksanaan, respon mahasiswa, dan Dosen terhadap Bahan ajar komik yang diketahui melalui pengisian angket observasi keterlaksanaan, respon mahasiswa dan Dosen. Hasil observasi keterlaksanaan dapat dilihat pada tabel 5.

Tabel 5. Hasil Rekapitulasi Observasi

\begin{tabular}{ccc}
\hline $\begin{array}{c}\text { Rerata Nilai Pertemuan } \\
\text { Pertama }\end{array}$ & $\begin{array}{c}\text { Rerata Nilai } \\
\text { Pertemuan Kedua }\end{array}$ & $\begin{array}{c}\text { Total Rerata Nilai } \\
\text { Keterlaksanaan }\end{array}$ \\
\hline 4.63 & 4.73 & 4.68 \\
\hline
\end{tabular}


Berdasarkan hasil observasi keterlaksanaan yang terdapat pada pada Tabel 5 di atas dapat dijelaskan bahwa nilai rata-rata total keterlaksanaan untuk semua pertemuan yaitu $\mathrm{KTR}=4.68$, nilai tersebut masuk ke dalam kategori "hampir seluruhnya terlaksana" $(4 \leq \mathrm{KTR}<5)$. Jadi, setelah dilakukan observasi keterlaksanaan pada setiap pertemuan, dapat disimpulkan bahwa Bahan ajar komikdinyatakan "praktis" untuk digunakan dalam proses belajar mengajar dan sebagai sumber belajar.

Kepraktisan komik pembelajaran dilihat dari hasil angket keterlaksanaan oleh pengamat, respon Dosen dan respon mahasiswa. Dalam kamus besar bahasa Indonesia, praktis diartikan mudah dan senang memakainya. Indikator kepraktisan komik pembelajaran adalah hasil respon Dosen sebagai praktisi komik pembelajaran.

Berdasarkan hasil observasi keterlaksanaan yang dilaksanakan komik pembelajaran dapat dinyatakan praktis. Hal ini disebabkan beberapa tahapan proses belajar mengajar menggunakan komik pembelajaran sangat mudah dan praktis digunakan baik oleh Dosen maupun mahasiswa. Penggunaan komik pembelajaran ini mudah dan praktis digunakan, hal ini bisa terlihat dari analisis nilai respon mahasiswa dan Dosen. Berdasarkan respon mahasiswa dan Dosen bahwa Bahan ajar komik memberikan respon yang positif. Makna positif disini menurut mahasiswa dan Dosen adalah Bahan ajar komik sangat cocok dan tepat digunakan dalam mata kuliah Botani Tingkat Rendah. Selain itu menurut respon mahasiswa dan Dosen komik pembelajaran sangat praktis digunakan, hal ini dikarenakan Bahan ajar komik yang digunakan tidak memerlukan koneksi internet, dan dapat dibawa kemana-mana sehingga ini memudahkan mahasiswa dalam mempelajarinya meskipun tidak menggunakan komputer/laptop. Selain itu Bahan ajar komik sangat membantu mahasiswa dalam belajar, dan memudahkan Dosen dalam mengajarkan materi Pteridophyta.

\section{b. Keefektifan Komik Pembelajaran Biologi}

Sumber belajar dapat dikatakan baik tidak cukup hanya dengan melihat kevalidan dan kepraktisannya, tetapi juga perlu dilihat keefektifan sumber belajar tersebut. Dengan demikian selain data tentang kevalidan dan kepraktisan, maka akan dikemukakan data tentang keefektifan Bahan ajar komik pada materi Pteridophyta dengan melihat hasil belajar mahasiswa. Berdasarkan analisis data hasil belajar mahasiswa Jurusan Pendidikan Biologi diperoleh hasil seluruh mahasiswa lulus $100 \%$ dengan rata-rata pada kategori baik merujuk pada pedoman edukasi UIN Alauddin. Sehingga dapat dikatakan bahwa pembelajaran pada materi Pteridophyta berhasil dan tingkat penguasaan mahasiswa terhadap materi Pteridophyta yaitu tinggi memiliki nilai $\geq 75$. 
Tabel 6. Distribusi Nilai Hasil Belajar Kognitif Mahasiswa

\begin{tabular}{|c|c|c|c|}
\hline Kategori & Rentang Nilai & Jumlah & Persentase (100\%) \\
\hline Baik sekali & $80,00-100,0$ & 22 & 92 \\
\hline Baik & $66,00-79,00$ & 2 & 8 \\
\hline Cukup & $56,00-65,00$ & - & - \\
\hline Kurang & $40,00-55,00$ & - & - \\
\hline Sangat kurang & $0,00-39,00$ & - & - \\
\hline Jumlah & & 24 & 100 \\
\hline \multicolumn{4}{|c|}{ Statistik Deskriptif } \\
\hline Nilai tertinggi & \multicolumn{3}{|c|}{94} \\
\hline Nilai terendah & \multicolumn{3}{|c|}{77} \\
\hline Standar deviasi & \multicolumn{3}{|c|}{4.87} \\
\hline Rata-rata & \multicolumn{3}{|c|}{86.92} \\
\hline Jumlah sampel & \multicolumn{3}{|c|}{24} \\
\hline
\end{tabular}

Tabel 6 menunjukkan bahwa rata-rata nilai hasil belajar mahasiswa dengan rentang nilai 66,00 - 79,00 (baik) sebanyak 2 (8\%) mahasiswa dan 80,00-100,00 (baik sekali) sebanyak $22(92 \%)$ mahasiswa. Pada tabel di atas juga menunjukkan bahwa rata-rata hasil mahasiswa yaitu 86.92 masuk dalam kategori sangat baik. Komik pembelajaran dapat dikatakan efektif apabila dapat dari hasil positif yang diberikan oleh sumber belajar kepada subjek penelitian yang dilihat dari hasil belajar mahasiswa. Apabila $80 \%$ mahasiswa atau lebih memenuhi nilai ketuntasan minimal maka media pembelajaran efektif digunakan. Pada penelitian ini keefektifan komik pembelajaran diukur melalui hasil belajar mahasiswa. Dalam kamus bahasa Indonesia kata efektif berarti mempunyai efek, pengaruh atau akibat. Menurut (Sugiyono, 2006), jika 80\% mahasiswa atau lebih memenuhi nilai KKM, maka $\mathrm{model} /$ media pembelajaran tersebut efektif digunakan.

\section{Evaluasi}

Hasil penilaian (evaluasi) pada pengembangan Bahan ajar komik pada materi Pteridophyta untuk mahasiswa sebagai sumber belajar telah memenuhi persyaratan, baik itu dari proses pertama yaitu analisis hingga sampai pada proses keempat yaitu implementasi termasuk di dalamnya kevalidan, kepraktisan, dan keefektifan komik pembelajaran biologi.

Analisis pada tahap awal dalam model pengembangan ADDIE digunakan sebagai acuan atau bahan pertimbangan dalam menentukan produk yang akan dikembangkan. Setelah mempertimbangkan atau memilih produk yang akan dikembangkan, maka dilanjutkan ke tahap desain yaitu merancang produk yang akan dikembangkan dalam hal ini Bahan ajar komikpada materi Pteridophyta. Selanjutnya, dilakukan pengembangan komik pembelajaran dan dilakukan uji kevalidan oleh dua validator ahli. Hasil uji kevalidan tersebut menunjukkan bahwa Bahan ajar komik layak untuk digunakan atau diimplementasikan di Jurusan Pendidikan Biologi sebagai sumber belajar mahasiswa (mahasiswa). Setelah Bahan ajar komik dinyatakan valid, maka dilakukan tahap selanjutnya yaitu implementasi atau uji coba terbatas di Jurusan Pendidikan Biologi. Pada tahap ini dilakukan 
pengenalan terhadap bahan ajar komik terlebih dahulu kepada mahasiswa dan Dosen mata kuliah Botani Tingkat Rendah. Selanjutnya dilakukan uji coba terbatas dalam proses belajar mengajar di dalam kelas dengan jumlah pertemuan 2 kali tatap muka. Setelah dilakukan pengenalan dan uji coba terbatas, dilakukan uji kepraktisan dan keefektifan komik pembelajaran biologi. Uji kepraktisan menggunakan angket observasi keterlakasanaan komik pembelajaran biologi, angket respon mahasiswa, dan angket respon Dosen. Berdasarkan data hasil observasi keterlakasanaan, Bahan ajar komik menunjukkan dapat terlaksana dengan kategori terlaksana baik. Selain itu, berdasarkan data hasil respon mahasiswa dan Dosen tersebut menujukkan bahwa Bahan ajar komik pada materi Pteridophyta mahasiswa praktis untuk digunakan. Keefektifan bahan ajar komik dapat dilihat dari hasil belajar mahasiswa. Berdasarkan data hasil belajar mahasiswa menunjukkan bahwa bahan ajar komik pada materi Pteridophyta untuk mahasiswa efektif untuk digunakan. Dengan demikian, dari tahap awal hingga tahap keempat dari model pengembangan $A D D I E$ dapat dikatakan bahwa sesuai dengan yang diharapkan yaitu valid, praktis, dan efektif.

Dengan demikian, hasil penelitian menunjukkan bahwa hasil belajar mahasiswa Jurusan Pendidikan Biologi setelah diberikan tes yaitu 100\% mahasiswa tuntas. Hal ini menunjukkan bahwa pembelajaran pada materi Pteridophyta berhasil dan tingkat penguasaan mahasiswa terhadap materi Pteridophyta memiliki nilai ratarata 86.92 (sangat baik). Hal tersebut disebabkan karena berbagai faktor, salah satunya yaitu sumber belajar/bahan ajar yang digunakan oleh mahasiswa dalam belajar karena sumber belajar merupakan sarana (tempat) mahasiswa memperoleh/menggalih berbagai informasi terkait dengan materi yang dipelajarinya (Ahmad, 2008). Dengan demikian, Dosen perlu menyediakan sumber belajar/bahan ajar yang berkualitas, sesuai dengan kebutuhan mahasiswa yang akan menggunakan sumber belajar/bahan ajar tersebut. Karakteristik khas Bahan ajar komik yaitu menonjolkan visualitas yang mana desainnya diperkaya oleh perpaduan teks, gambar, dan penjelasan materi. Semua komponen yang terdapat dalam komik pembelajaran, membuat mahasiswa dapat membaca, melihat gambar, komik, dan penjelasan materi sehingga memudahkan mahasiswa dalam belajar. Berdasarkan hal tersebut, hasil belajar mahasiswa menjadi lebih baik dan tingkat penguasaan mahasiswa terhadap materi Pteridophyta sangat baik. Hal ini dikarenakan Bahan ajar komik mampu mewadahi karakteristik mahasiswa yang beragam dan mahasiswa merasa senang ketika bahan ajar yang digunakannya bervariasi dan menarik.

(Syaichudin, 2016) mengemukakan bahwa penggunaan media gambar pada saat pelaksanaan kegiatan pembelajaran akan dapat membantu daya ingat mahasiswa, apalagi jika gambar yang ditampilkan divariasi dengan desain warna yang menarik sehingga menimbulkan kesan senang pada mahasiswa dalam mengikuti pembelajaran tersebut. Perasaan senang tersebut akan membekas dalam diri mahasiswa dan memberikan kontribusi tersendiri terhadap keberhasilan belajar. Selain meningkatkan hasil belajar pada kognitif, media gambar juga meningkatkan hasil belajar pada aspek psikomotoris. Media gambar banyak terjaring keterampilan kegiatan belajar mengajar, diantaranya pada aspek mengajukan pertanyaan, menggunakan alat atau media. Penelitian ini juga

\section{Syahriani. $d k k$}


diperkuat dari hasil penelitian (Pritandhari, 2016) bahwa Respon mahasiswa terhadap kegiatan pembelajaran dikelas terlihat lebih antusias menggunakan media komik strip. Mereka lebih berminat untuk mengetahui bagaimana bentuk gambar dan cerita yang akan ditampilkan dalam media komik strip sehingga ketika mereka membaca media komik strip secara tidak langsung mereka mempelajari materi pembelajaran. Minat belajar mahasiswa cenderung meningkat jika dibandingkan dengan sebelum menggunakan media komik strip.

\section{KESIMPULAN}

Berdasarkan hasil penelitian dan pengembangan bahan ajar komik materi Ptridophyta untuk mahasiswa Jurusan Pendidikan Biologi, maka dapat disimpulkan bahwa Komik Pteridophyta yang dikembangkan termasuk dalam kategori valid. Dengan nilai kevalidan untuk setiap aspek penilaian yaitu kelayakan isi adalah 4.17; kelayakan penyajian adalah 4.36; kelayakan media adalah 4.57 dan kelayakan bahasa adalah 4.70 . Jadi nilai rata-rata kevalidan komik pembelajaran adalah 4.45 termasuk dalam kategori "valid" $(4 \leq \mathrm{Va}<5)$. Komik Pteridophyta yang dikembangkan termasuk dalam kategori praktis. Berdasarkan penilaian mahasiswa, 93\% mahasiswa menyatakan bahwa penggunaan isi dan efek-efek pada komik pembelajaran membuat belajar menjadi lebih menyenangkan dan tidak bosan dalam mempelajarinya. Selain itu berdasarkan penilaian Dosen, 95\% Dosen menyatakan bahwa animasi \& komik yang ditampilkan menarik, Bahan ajar komik ini memudahkan Dosen dalam mengajar mata kuliah botani tingkat rendah. Komik Pteridophyta yang dikembangkan termasuk dalam kategori efektif. Dengan menunjukkan bahwa pembelajaran pada materi Pteridophyta berhasil dan tingkat penguasaan mahasiswa terhadap materi Pteridophyta memiliki nilai rata-rata 86.92 (sangat baik) dan pencapaian hasil belajar siswa 100\% memenuhi nilai ketuntasan.

\section{DAFTAR PUSTAKA}

Ahmad, N. S. dan R. (2008). Media Pengajaran. Bandung: Penerbit Sinar Baru Algensindo.

Arikunto, S. (2013). Dasar-dasar evaluasi pendidikan. Jakarta: Bumi Aksara.

Arsyad, A. (2009). Media Pembelajaran. Jakarta: PT.Raja Grafindo Persada.

Arsyad, A. (2011). Media Pembelajaran. Jakarta: PT.Raja Grafindo Persada.

Astuti, N. W. (2012). Pengembangan Media Cerpen Biologi untuk SMA/MA Kelas X Semester Gasal Materi Pokok Virus. 368.

Bingimlas, K. A. (2009). Barriers to the successful integration of ICT in teaching and learning environments: A review of the literature. Eurasia Journal of Mathematics, Science and Technology Education, 5(3), 235-245. https://doi.org/10.12973/ejmste/75275

Fajriah, Z. L., \& Anggereini, E. (2016). Pengembangan Edu Komik Sebagai Bahan Ajar Berbasis Pendidikan Karakter Pada Materi Interaksi Mahluk Hidup Dan Lingkungannya Di Sekolah Menengah Pertama. Biodik, 2(1).

Lestari, I. (2013). Pengembangan Bahan Ajar Berbasis Kompetensi (Sesuai dengan Kurikulum Tingkat Satuan Pendidikan). Padang: Akademia Permata.

Listiyani, I. M., \& Widayati, A. (2012). Pengembangan Komik Sebagai Media 
Pembelajaran Akuntansi Pada Kompetensi Dasar Persamaan Dasar Akuntansi Untuk Siswa Sma Kelas Xi. Jurnal Pendidikan Akuntansi Indonesia, 10(2), 8094. https://doi.org/10.21831/jpai.v10i2.914

Maksum, A. (2012). Pengumpulan data. JURNAL Metode Pengumpulan Data, agustus, 107.

Pritandhari, M. (2016). Penerapan Komik Strip Sebagai Media Pembelajaran Mata Kuliah Manajemen Keuangan Mahasiswa Universitas Muhammadiyah Metro. PROMOSI (Jurnal Pendidikan Ekonomi), 4(2), 1-7. https://doi.org/10.24127/ja.v4i2.631

Puspitorini, R., Prodjosantoso, A. K., Subali, B., \& Jumadi, J. (2014). Penggunaan Media Komik Dalam Pembelajaran Ipa Untuk Meningkatkan Motivasi Dan Hasil Belajar Kognitif Dan Afektif. Jurnal Cakrawala Pendidikan, 3(3), 413-420. https://doi.org/10.21831/cp.v3i3.2385

Sadikin, A., Saudagar, F., \& Muslim, F. (2018). Development of the Biology Textbook of Process Evaluation and Learning Outcome for Students in Biology Education, $\begin{array}{llll}\text { University of Jambi. } & \text { BIODIK, } & 4(2), & \text { 83-94. }\end{array}$ https://doi.org/https://doi.org/10.22437/bio.v4i2.6120

Saputro, A. D. (2015). Aplikasi Komik sebagai Media Pembelajaran. M U A D D I B, 05(01), ISSN 2088-3390.

Sugiyono. (2006). Metode Penelitian Kuantitatif Kualitatif dan $R \& D$. Bandung: Alfabeta.

Syafa'ah, A. (2014). Pengembangan Bahan Ajar Berbasis Cerita Bergambar / Komik Materi Pokok Konsep Pembagian Dengan Pendekatan Inquiry Siswa Kelas III SDN Jatimulyo II Malang. Skripsi S1 Pendidikan. Universitas Islam Negeri Maulana Malik Ibrahim Malang.

Syaichudin, R. D. N. dan M. (2016). Pengembangan Media Komik Pembelajaran Matematika Untuk Meningkatkan Pemahaman Bentuk Soal Cerita Bab Pecahan Pada Siswa Kelas V SDN Ngembung.

Ubhiyati, A. A. dan N. (2007). IImu Pendidikan. Jakarta: Rineka Cipta. 